\title{
Institution Investor and Corporate Innovation Investment: View of Dynamic Endogeny
}

\author{
Le XU \\ Economic Management \\ School of Xi'an Technological University \\ Xi'an,China \\ xule_laoxie@163.com
}

\author{
Jian-Ping HOU \\ Economic Management \\ School of Xi'an Technological University \\ Xi'an, China \\ hjp0498@163.com
}

\begin{abstract}
This paper makes a theoretical analysis on institutional investors and r\&d investment, and the basic model of dynamic endogenous sexual relationship analysis was established. In the empirical study, the paper takes the data of domestic listed companies as samples, the dynamic endogenous relationship of variables is analyzed systematically. Research suggests that: there is a significant dynamic endogenous relationship between the two variables, and institutional investors may have value creation effects.
\end{abstract}

Keywords-R\&d spending; institutional investor; dynamic endogeneity;corporate governance

\section{PREFACE}

Innovation investment is critical for economic development and corporate growth, it can raise corporate long term competitiveness, bring about high revenue to stock holder, and become a strategic investment to realize corporate stable growth and sustainable development. In the times of intelligence economy, R\&D investment is more and more important. The performance of innovation is to $R \& D$ invest to corporate, [3] since innovation investment revenue is in a long term and high risk, China corporate managers are not willing to invest the innovation, and it leads to the phenomenon of insufficient innovation investment ratio existing in the corporate.

With the improvement of innovation economics theory system research and corporate governance theory, the relationship gradually gets focused among corporate governance, research investment and technological innovation. Organizational control theory drives the center of corporate governance research moved from value distribution to value innovation based on innovation economics, and the theory takes the opinion that effective corporate governance could drive corporate technological innovation through effective allocation and reasonable resource integration. The institution investor develops rapidly in the Europe and US. And plays an important role in corporate governance and its improvement. The effect of institution investor in the issue of corporate governance caused the focus of the field of theory and practice. In the recent years, China issued the policy of "ultra-convention development of institution investor" as an important measures to improve the investor structure in the capital market, tries to improve the governance level of China's listed company through raising the ratio of institution investor, further to raise the innovation investment ratio and innovation performance of the corporate. Institution investor has a certain investment preference, common focus on the index of corporate R\&D investment, and its determination affected by $R \& D$ investment. This article will research and test the relations of institution investment and $R \& D$ investment through the facts from the view of dynamic endogen.

\section{LITERATURE REVIEW}

Innovation is the main impetus of corporate development, and needs take relevant risks. Innovation investment focuses more attention on the revenue in the future, compared with present benefit. [5] $R \& D$ investment is a long term investment, and it will increase the cost of corporate in a short term, even leads to profit declines in a short term. It is a nearsightedness that investor only focuses on the present profit level, and makes investment determination by that. The relations have three opinions - negative correlation, positive correlation and uncorrelated - based on whether the institution investor is in nearsightedness or not.

Majority researches take the opinion that institution investor and innovation investment are in a positive correlation. Aghion etc. raises the opinion that institution investor has some positive effect to $R \& D$ expenditure, more stock held by institution, and more innovation investment; Bushee thinks although the existing of short-term behavior of the institution investor and nearsightedness of manager level and the manager level reduce $R \& D$ investment intentionally in order to avoid institution investor underselling since they are disappointed to the business and valuate the company stock price by mistake in a short term, the institution investor with a big stock quantity in a long term has a strong momentum to take some cost to supervise the manager level not reducing R\&D expenditure according with short-term profit target. Therefore institution investor supervises and punishes the manager level to guarantee makes R\&D investment for long-term capital maximization, not for short-term profit target, i.e., when institution investor takes a high stock ratio, company manager level will not turn around the trend of profit declining through reducing the expenditure of research. [6]

The research that institution investor and R\&D investment are in a negative correlation holds the opinion that institution investor is a near-sighted investor, and it 
chases short-term profit. [7] Graves thinks institution investor affects the corporate determination, medium long term investment will be restrained in the company that high ratio stock held by institution investor, and it leads to the decline of company comprehensive competitiveness to restrain the $R \& D$ investment. [8]

Some researcher thinks there is no relation between institution investor and company innovation investment. Ren Haiyun researches and finds institution investor has no adjustment effect to R\&D investment; Zhao Hongjiang etc. researches and finds institution investor has a generally insignificance explanation effect to company $R \& D$ investment. Chung etc. researches and indicates that institution investor has no effect to the R\&D investment.

\section{THEORY ANALYSIS AND HYPOTHESIS}

Generally, innovation investment revenue is in a long term and has some failure risk, manager utility is always based on the company short term performance. Different from manager level, strong stock holder tend to the innovative program of strategic target and endurance, in long term and risk. It guarantee the manager level chasing the interests of stock holder in the innovation activities through ownership structure centralization and a closer work between strong stock holder and company high level management team. The corporate chases innovation activities and better innovation efficiency, with corporate ownership structure centralization and control moved from high level manager to strong stock holder. However, the conflict does not only exist between the stock holders and the manager level, but also between the stock holders. Controlling stock holder tends to taking private revenue. When ownership becomes over centralized, they will be more serious and will not take risks further make innovation investment since they need take majority of risk.

From the momentum of institution investor governance momentum, Lin Yuchen, Tan Jinsong raise the opinion that no existed document specifies the relations of institution investor and corporate governance, whether causal relationship, influencing each other or something else. Based on the opinion of stock holder positivism, Gillan and Starks and Cornett et al. think compared with corporate stock holder and retail investor, institution investor has the advantage of scale, overcomes the situation of strong stock holder internal controlling, and strong momentum and ability to attend corporate governance, and then institution investor raises the company performance through improvement of invested company's governance level. Therefore, we think institution investor chooses to invest the company of a good governance level, or improves the governance level through controlling rights competitiveness after investment. The both sides have a endogenous relations. Existed relation researches between institution investor and corporate governance, majority of the researches only consider the value creation effect, ignore the value selection effect of institution investor in corporate governance, even the two effects considered as value creation effect. Since except that institution investor affects corporate governance, corporate governance also affects institution investor in feedback effect, we cannot analyze the causal relationship between institution investor and corporate governance, endogeny caused by the existence of casual relationship, research result may be biased to ignore the endogeny relationship. Existed researches have not considered the endogeny relationship between institution investor and corporate governance.

What corporate governance effect does institution investor have, whether value selection effect, value creation effect, or both, this question has not answered consistently. Majority of institution investor takes a big ratio of stocks, and its existence can reduce the behavior of "thumb a lift" of minority stockholder; secondly, when holding a certain ratio of stocks, institution investor have the ability to join the corporate governance; lastly, institution investor can use the professional knowledge to analyze and distinguish the listed company, and more comprehensive assessment made from multi views. Many researches indicates institution investor more and more tends to long term investment, join the corporate governance actively, affect and improve the corporate governance with more active practices, further, to improve the company innovation ability, i.e. have the ability of value selection, and have the ability of value creation possibly at the same time. Thus this article raises hypothesis as follow:

Hypothesis 1: institution investor has the value selection effect, i.e. a positive correlation between previous research strength and current stock holding of institution investor.

Hypothesis 2: institution investor has the value creation effect, i.e. a positive correlation between previous stock holding of institution investor and current research strength.

\section{A. Sample Selection and Data Source}

This article selects the research expenditures of 357 listed companies of information industry during 2009-2013 as the research sample, research expenditure wholly adopts the item "cash paid for others relevant with business activities" in the company annual report, but the research data names are different, e.g. technique development fee, research fee, new product development fee, and the annual data are from Juchao information net. Stock holding ratio data by institution investor, research expenditure data, and relevant financial index data are all from the CSMAR data base of Shenzhen Guotaian information and Technology Company. The sample get rid of companies less than one year since listed in order to avoid the research expenditure affected by the issue of listed on the market, and the samples lack of research data in continuous two years especially. After the disposal, 998 mixture sample data of 280 listed companies in five years, and sampling check made to the data to keep reliability of data with the statistics software of STATA 12.0.

\section{B. Research Variables}

Since research investment strength as the variable in this article, the literature around the world measures the research investment strength mainly with the ratio of research investment and total assets, and the ratio of research investment and sale. In order to compare with other literature, the two index used to describe research investment strength in this article. 
TABLE I. DEFINITION AND DESCRIPTION OF VARIABLES

\begin{tabular}{|c|c|c|c|}
\hline & Variable name & $\begin{array}{l}\text { Variable } \\
\text { code }\end{array}$ & Variable definition \\
\hline \multirow{2}{*}{$\begin{array}{l}\text { Main } \\
\text { variable }\end{array}$} & Research strength & $R D$ & $\begin{array}{c}\text { Research expenditure/sales } \\
\text { revenue }\end{array}$ \\
\hline & $\begin{array}{l}\text { Stock holding } \\
\text { ratio by institution } \\
\text { investor }\end{array}$ & INST & $\begin{array}{c}\text { Stock holding by } \\
\text { institution } \\
\text { investor/company total } \\
\text { stock } \\
\end{array}$ \\
\hline \multirow{8}{*}{$\begin{array}{l}\text { Control } \\
\text { variable }\end{array}$} & $\begin{array}{l}\text { asset-liability } \\
\text { ratio }\end{array}$ & $L E V$ & total liabilities/total assets \\
\hline & Scale of company & SIZE & $\begin{array}{c}\text { natural logarithm of total } \\
\text { assets }\end{array}$ \\
\hline & $\begin{array}{l}\text { Net cash flow } \\
\text { from operation }\end{array}$ & $\mathrm{CASH}$ & $\begin{array}{c}\text { Cash net flow of } \\
\text { operations/ total asstes }\end{array}$ \\
\hline & Corporate growth & GROW & $\begin{array}{c}\text { (ain business revenue at } \\
\text { the end of year } t \text { / Main } \\
\text { business revenue for } t-1 \\
\text { years)-1 }\end{array}$ \\
\hline & $\begin{array}{l}\text { price / book value } \\
\text { ratio }\end{array}$ & $P B$ & $\begin{array}{l}\text { Price/ net asset value per } \\
\text { share }\end{array}$ \\
\hline & $\begin{array}{c}\text { ownership } \\
\text { concentration }\end{array}$ & $H 5$ & $\begin{array}{l}\text { Ratio sum of square of the } \\
\text { first five strong stock } \\
\text { holder }\end{array}$ \\
\hline & $\begin{array}{l}\text { Company } \\
\text { profitability }\end{array}$ & $E P S$ & Net profit/ total stock \\
\hline & $\begin{array}{c}\text { executive } \\
\text { compensation }\end{array}$ & $P A Y$ & $\begin{array}{l}\text { natural logarithm of total } \\
\text { tive compensation }\end{array}$ \\
\hline
\end{tabular}

\section{Research Model}

Demonstration faces two endogeny issue: (1) missing variable: some factors hard to observe affect the stock holding determination of institution investor and the company research expenditure; (2) reciprocal causation: stock holding determination of institution investor and the company research expenditure affect each other very strong and it leads to serious endogeny issue existing in the model. Meanwhile, in practice, research expenditure is measured and published at regular intervals, company research expenditure affected by stock holding of institution investor in hysteretic nature. There will be a biased conclusion if ignoring the influence of period. Therefore, when studying the relations of stock holding of institution investor and research strength, the factor of period must be considered, so called "dynamic endogeny issu" happens.

Based on the consideration above, to test hypothesis 1, we build dynamic model 1 as follow with company research strength as the explanatory variable.

$I N S T_{\mathrm{i}, t}=\alpha_{1}+\lambda_{1} I N S T_{i, t-1}+\beta_{1} R D_{i, t}+\beta_{2} R D_{i, t-1}+\beta_{3} R D_{i, t-2}+\sum_{p} \varphi_{p} Z_{p, i, t}+\omega_{i, t}$

To test hypothesis 2, we build dynamic model 2 as follow with stock holding of institution investor as the explanatory variable.

$$
R D_{\mathrm{i}, \mathrm{t}}=\alpha_{2}+\lambda_{2} R D_{i, t-1}+\mu_{1} I N S T_{i, t}+\mu_{2} I N S T_{i, t-1}+\mu_{3} I N S T_{i, t-2}+\sum_{q} \gamma_{q} Z_{q, i, t}+\varepsilon_{i . t}
$$

\section{DEMONSTRATION RESULT AND ANALYSIS}

\section{A. Descriptive Statistics}

TABLE II. DESCRIPTIVE STATISTICS

\begin{tabular}{c|c|c|c|c}
\hline variable & $\begin{array}{c}\text { Mean } \\
\text { value }\end{array}$ & $\begin{array}{c}\text { Standard } \\
\text { deviation }\end{array}$ & $\begin{array}{c}\text { Max } \\
\text { value }\end{array}$ & Min value \\
\hline RD1 & 0.0760 & 0.0842 & 0.984 & 0.000145 \\
\hline RD2 & 0.0338 & 0.0290 & 0.257 & 0.0000104 \\
\hline INST & 5.835 & 4.842 & 40.61 & 0.052 \\
\hline H5 & 0.143 & 0.0939 & 0.506 & 0.00904 \\
\hline PB & 4.0729 & 3.940 & 73.249 & 0.307 \\
\hline EPS & 0.386 & 0.423 & 2.14 & -2.557 \\
\hline SIZE & 21.284 & 0.925 & 26.999 & 19.0567 \\
\hline CASH & 0.0352 & 0.0722 & 0.358 & -0.240 \\
\hline GROW & 0.214 & 0.533 & 10.462 & -0.791 \\
\hline LEV & 0.311 & 0.194 & 0.932 & 0.0110 \\
\hline PAY & 15.0192 & 0.629 & 17.771 & 12.9854 \\
\hline & & & &
\end{tabular}

\section{B. Multicollinearity Test}

Variance inflation factor of variable calculated by statistics software STATA12.0 in this article, empirical rule indicates VIF max value not exceeding 10 . Per table 3, the max values of VIF output are $1.08,1.71$ respectively in the two models, far less than 10 , so not a serious multicollinearity issue.

TABLE III. MULTICOLLINEARITY INSPECTION RESULT

\begin{tabular}{c|c|c|c|c}
\hline variable & VIF & 1/VIF & VIF & 1/VIF \\
\hline RD2 & 1.01 & 0.989 & & \\
\hline INST & & & 1.10 & 0.908 \\
\hline H5 & 1.03 & 0.973 & & \\
\hline PB & 1.08 & 0.930 & & \\
\hline EPS & 1.07 & 0.933 & 1.23 & 0.812 \\
\hline SIZE & 1.07 & 0.935 & 1.71 & 0.585 \\
\hline CASH & & & 1.09 & 0.917 \\
\hline GROW & 1.05 & 0.954 & & \\
\hline LEV & & & 1.51 & 0.662 \\
\hline PAY & & & 1.34 & 0.748 \\
\hline $\begin{array}{c}\text { Mean } \\
\text { VIF }\end{array}$ & 1.05 & & 1.33 & \\
\hline \multicolumn{2}{|l}{} & & &
\end{tabular}

\section{Demonstration Inspection Result}

Before model estimation, to confirm the length of lag phase firstly, per the researches before, it is thought that twoyear lag phase could reflect majority information in the past, this article uses the confirm method of lag phase by Wintoki etc. (2010) for reference, and thinks it can meet erogeneity hypothesis of instrument variable by 2 phases lag of explanatory variable and dependent variable. 
TABLE IV. REGRESSION RESULT OF STOCK HOLDING OF INSTITUTION INVESTOR AND RESEARCH STRENGTH

\begin{tabular}{|c|c|c|c|c|}
\hline variable & Model I & $\begin{array}{l}\text { Model } \\
\text { I }\end{array}$ & Model II & Model II \\
\hline $\begin{array}{c}\text { Regression } \\
\text { method }\end{array}$ & OLS & GMM & OLS & GMM \\
\hline $\begin{array}{c}\text { Variable } \\
\text { name }\end{array}$ & INST & INST & $\mathrm{RD}$ & $\mathrm{RD}$ \\
\hline RD & $\begin{array}{c}17.136 * * \\
(3.47)\end{array}$ & & & \\
\hline $\mathrm{RD}(-1)$ & & $\begin{array}{l}7.0259 \\
(0.91)\end{array}$ & & $\begin{array}{c}0.716^{* * * *} \\
(7.39)\end{array}$ \\
\hline $\mathrm{RD}(-2)$ & & & & $\begin{array}{l}0.145^{*} \\
(1.85)\end{array}$ \\
\hline INST & & & $\begin{array}{c}0.000661 * * * * \\
(3.63)\end{array}$ & \\
\hline INST(-1) & & $\begin{array}{c}0.469^{* * * *} \\
(9.05)\end{array}$ & & $\begin{array}{c}0.000848^{*} \\
(1.29)\end{array}$ \\
\hline INST(-2) & & $\begin{array}{l}0.0213 \\
(0.45) \\
\end{array}$ & & \\
\hline LEV & & & $\begin{array}{c}-0.0149 * * * \\
(-2.80)\end{array}$ & $\begin{array}{c}-0.00560 \\
(-0.94)\end{array}$ \\
\hline SIZE & $\begin{array}{c}0.545 * * * \\
(3.42)\end{array}$ & $\begin{array}{c}0.2889 \\
(1.48)\end{array}$ & $\begin{array}{c}-0.00713^{* * * *} \\
(-6.00)\end{array}$ & $\begin{array}{c}-0.00241 * \\
(-1.70)\end{array}$ \\
\hline GROW & $\begin{array}{c}0.475^{*} \\
(1.73)\end{array}$ & $\begin{array}{c}0.420 \\
(0.63)\end{array}$ & & \\
\hline H5 & $\begin{array}{c}-8.0746^{* * * *} \\
(-5.24)\end{array}$ & $\begin{array}{c}-5.177 \\
* * * \\
(-2.97)\end{array}$ & & \\
\hline PB & $\begin{array}{c}0.166 * * * \\
(4.42)\end{array}$ & $\begin{array}{c}0.543 * * * \\
(4.51)\end{array}$ & & \\
\hline EPS & $\begin{array}{c}3.0616 * * * \\
(8.76)\end{array}$ & $\begin{array}{c}1.591 * * * \\
(3.46)\end{array}$ & $\begin{array}{c}-0.00468^{* * *} \\
(-2.12)\end{array}$ & $\begin{array}{c}-0.00670^{*} \\
(-1.63)\end{array}$ \\
\hline $\mathrm{CASH}$ & & & $\begin{array}{c}0.0278^{* * *} \\
(2.29) \\
\end{array}$ & $\begin{array}{l}0.0284 \\
(1.36) \\
\end{array}$ \\
\hline PAY & & & $\begin{array}{c}0.0194 * * * \\
(12.54)\end{array}$ & $\begin{array}{c}0.00685^{* * * *} \\
(2.77)\end{array}$ \\
\hline $\mathrm{C}$ & $\begin{array}{c}-7.156^{* * *} \\
(-2.07) \\
\end{array}$ & $\begin{array}{c}-5.404 \\
\left(\begin{array}{l}-1.27 \\
\end{array}\right) \\
\end{array}$ & $\begin{array}{c}-0.104 * * * \\
(-4.10)\end{array}$ & $\begin{array}{c}-0.0445^{*} \\
(-1.66) \\
\end{array}$ \\
\hline $\mathrm{R} 2$ & 0.139 & 0.495 & 0.172 & 0.633 \\
\hline AR(1) Test & & 0.016 & & 0.011 \\
\hline $\mathrm{AR}(2)$ Test & & 0.531 & & 0.625 \\
\hline Hansen Test & & 0.249 & & 0.437 \\
\hline
\end{tabular}

Ps: ***,**,* means significant at the level of $1 \%, 5 \%, 10 \%$ respectively; The number in the bracket is $t$ in the OLS regression method, the number in the bracket is $z$ in GMM regression method.

From goodness of fit index R2 of model I and model II in table 4 , it raises the explanatory ability of model to use GMM method. About stock holding ratio by institution investor affected in dynamic endogeny by research strength, observe by the demonstration result of model I : (1) current stock holding ratio by institution investor is not significantly affected by current research strength. (2)current stock holding ratio by institution investor is also insignificantly affected by previous research strength. And it denies hypothesis 1, i.e. institution investor does not have value selection effect. From the demonstration of model II, considering dynamic endogeny, (1) no significant affect between current stock holding ratio by institution investor and current research strength. (2) a positive correlation between previous stock holding of institution investor and current research strength, accordant with hypothesis 2, but the both side are outstanding at the significance level $10 \%$, indicating listed company research expenditure limited affected by stock holding ratio of institution investor, i.e. weak value creation effect. Maybe because the result of company research activities is of uncertainty and hysteretic nature, institution investor may select the company of good business, not of high research expenditure. After company invests a lot in research, and it will focus the company development in the future. Higher stock holding ratio of institution investor may improve corporate governance level, but the governance function of institution investor is not significant.

This article inspects whether serial correlation of first order and second order exists in generalized method of moment estimation with AR (1), AR (2). Hansen Test inspects whether the selection of level instrument variable is appropriate in generalized method of moment estimation, and result is inspection passes.

\section{Robustness Test}

This article make robustness test of two sides to inspect the reliability of the conclusion above. Firstly, considering extreme value may affect the regression result, the value of less than $1 \%$ and more than $99 \%$ replaced by $1 \%$ and $99 \%$ respectively with getting rid of the samples of explanatory variable value " 0 " and the method of winsorize. Robustness regression result gets regressed again, and the result still stays the same. Secondly, considering error exists in disequilibrium sample, further, this article regresses the data again with equilibrium sample, and the result stays the same. And it indicates that the conclusion is of high stability in this article.

\section{RESEARCH CONCLUSION AND ADVICE}

The research whether institution investor has corporate effect and what effect institution investor has. Majority consider stock holding by institution investor as an exogenous power, ignore the dynamic relations between institution investor and company research expenditure, and the data of stock holding by institution investor and company research strength of the the same period get regressed. Only minority of document is aware of the relations of endogeny and dynamic, but there is no deeper research. This article analyzes theoretically the dynamic endogeny relations of stock holding ratio by institution investor and research strength, and makes empirical test through dynamic panel data of the listed company in the field of information industry and GMM estimation method. The results indicate no significant relations between stock holding ratio by institution investor and research strength maybe that is the result of dynamic endogeny relations introduced. Positive correlation between previous stock holding ratio by institution investor and current research strength, institution investor may have value creation effect. No significant affect between previous research strength and current stock holding ratio by institution investor, and no value selection effect of institution investor. The advices as follow per the disadvantages of this article: (1) when research the issues of institution investor, institution investor cannot be considered 
in the same nature, and the nature should be differentiated appropriately. (2) The selection of variables is in over singleness, maybe not enough demonstration of dynamic endogeny relations between stock holding ratio by institution investor and research strength, and it will be the key point of following research.

\section{ACKNOWLEDGMENT}

Fund project: Special scientific research project of education department of shaanxi province (16JK1353), President of Xi'an Technological University (XAGDXJJ15018)

\section{REFERENCES}

[1] Ding MENG, Yu-Peng YI, Zhi-Chao XU. The empirical research on the influence of high-tech enterprise corporate governance on $\mathrm{r} \& \mathrm{~d}$ investment--Based on the perspective of industry differences [J].Shanghai's financial, 2013(05):98-102.

[2] Lee, O'Neill. Ownership structures and R\&D investments of US and Japanese firms: Agency and stewardship perspectives [J]. Academy of Management Journal, 2003, 46(2):212-225.

[3] Bin WANG, Wei-Min XIE, Chu-Hong ZENG. Institutional ownership, corporate governance and $\mathrm{R} \& \mathrm{D}$ input of listed companies - empirical evidence from listed companies in China [J].Scientific and technological progress and countermeasures, 2011, 28(06):78-82.

[4] Gillan, Starks. Corporate governance proposals and shareholder activism: The role of institutional investors [J]. Journal of financial Economics, 2000, 57(2):275-305.

[5] Aghion, Van Reenen, Zingales. Innovation and institutional ownership[R].National Bureau of Economic Research, 2009.

[6] Bushee. The influence of institutional investors on myopic R\&D investment behavior [J]. Accounting review, 1998, 73(3):305-333.

[7] Ying-Zhao LI, Ji-Hui WU. Research on the relationship between institutional investors and $R \& D[J]$.Technology management research, 2013 (23): 187-190.

[8] Graves. Institutional ownership and corporate R\&D in the computer industry [J]. Academy of Management Journal, 1988, 31(2):417-428.

[9] Hong-Jiang ZHAO, Hui XIA. Empirical study on the relationship between institutional investor holding and listed companies' innovative behavior [J]. Chinese soft science, 2009 (05): 33-40.

[10] Chung, Shen. Corporate Governance and Market Reactions to Capital and R\&D Investment Announcements [D]. 2009.

[11] Yu-Chen LIN, Jin-Song TAN .Institutional investors and corporate governance_ literature review and research framework Chen LIN[J].Accounting and economic research, 2013 (5) : 70-80. 